\title{
Antifungal Properties of Citrullus colocynthis Leaves Extracts Against Vaginal Candida Infection
}

\author{
Wael A. Alsubhi' ${ }^{1}$ Ahmed M. Al-Hejin ${ }^{1,2}$, Kulvinder S. Saini' ${ }^{1}$, Mohamed Abu-Zaid ${ }^{1}$, Mohamed Morsi M. \\ Ahmed $^{3}$ \\ 1Department of Biological Sciences, Faculty of Science, P.O. Box 80203, King Abdulaziz University, Jeddah, 21589, Saudi Arabia. \\ ${ }^{2}$ King Fahad Medical Research Center, P.O. Box 80216, King Abdulaziz University, Jeddah, 21589, Saudi Arabia. \\ ${ }^{3}$ Nucleic Acids Research Dept., Genetic Engineering, and Biotechnology Research Institute (GEBRI). City for Scientific Research and Technological \\ Applications. Alexandria, Egypt.
}

Correspondence Author: Wael Alsubhi, Department of Biological Sciences, Faculty of Science, P.0. Box 80203, King Abdulaziz University, Jeddah, 21589, Saudi Arabia

Email: waelalsubhi@gmail.com

Received date: 12 December 2018, Accepted date: 10 February 2019, Online date: 25 February 2019

Copyright: (c) 2019 Wael Alsubhi et al., This is an open-access article distributed under the terms of the Creative Commons Attribution License, which permits unrestricted use, distribution, and reproduction in any medium, provided the original author and source are credited.

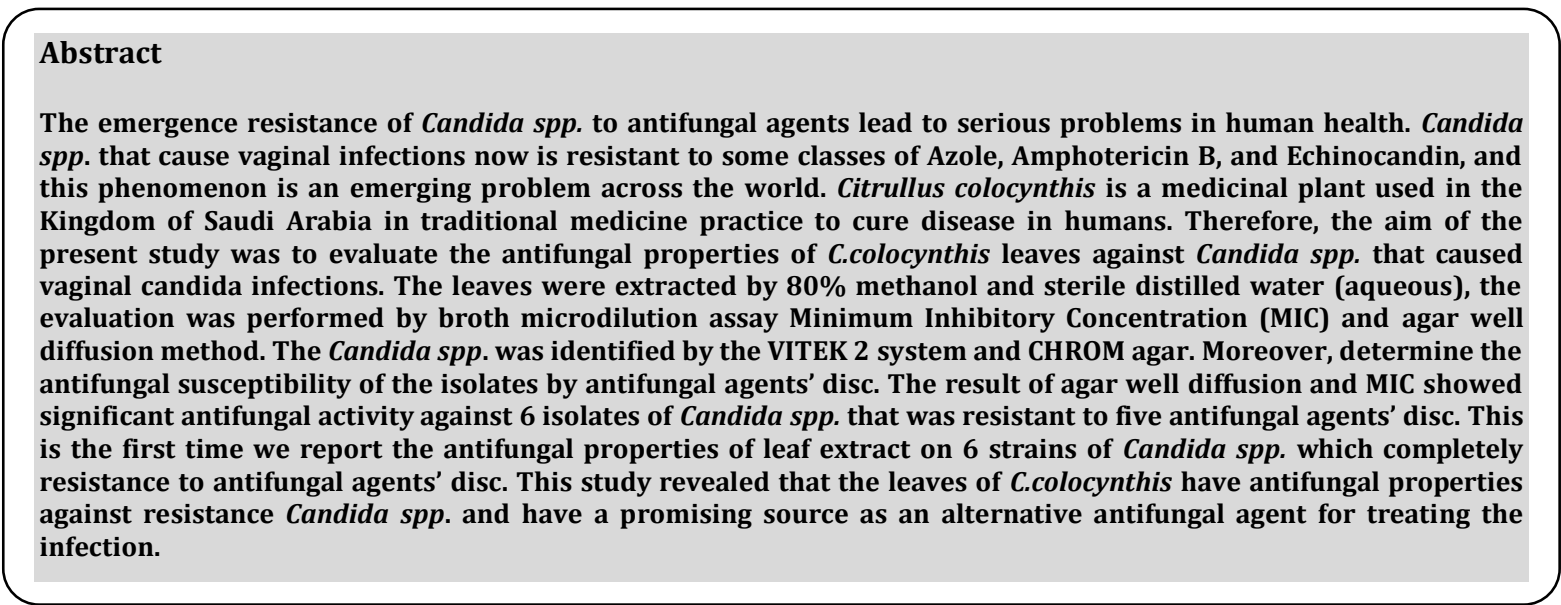

Key words: Candida spp, medicinal plant, Citrullus colocynthis extract, Vaginal Candida Infections, bioactive compounds, antifungal resistance

\section{INTRODUCTION}

From ancient times, mankind has used medicinal plants and their extracts for the treatment and prevention of many diseases. The use of medicinal plants dates back to the pre-Paleolithic time at least 60 thousand years ago, while in Sumerians civilization and India Ayurveda they found written evidence for used medicinal plants before 5,000 years ago. In ancient Egypt, medicinal plants were mentioned in Egyptian medical papyri [1-2]. Different ancient cultures were developed their own medicinal plant's system independently to cure their own illness using natural products [3]. According to the World Health Organization (WHO, 2005) most people in the world depending on medicinal plants for primary health care and that estimate up to $80 \%$ [4]. The natural products of medicinal plants possess an important role in diseases prevention and treatment. They consider one of the most resources as alternative drugs that contain several active compounds or defined as bioactive compounds such as Flavonoids, Phytic acid, Alkaloids, Terpenoids, Phenolic compounds, Sterols, Steroids, Essential Oils, Glycosides, Lignins, Tannins, Saponins, Anthocyanins and those are the most important bioactive compound [5]. Many researchers have investigated the effect of medicinal plants which used traditionally by indigenous healers. They were found most of the medicinal plants have therapeutic activities such as anti-diabetic, anti-inflammatory, antimalarial, anticancer activity, antifungal activity, antibacterial activity, antioxidant, antiviral activity, anticarcinogenic, wound healing effect, and anti-leprosy [6-7]. Some of the bioactive compounds may act by inhibiting the growth, damage the cellular membrane, intervene with microbial metabolism or phospholipid cell 
membranes which has an effect on permeability and lead to loss cellular constituents, and modification of signal transduction and gene expression pathways [8-9]. Vagina infections one of the most global health problem for women [10]. They exist as normal flora living on the human body that can found inside the gut, mouth, throat, and skin without causing any harm [11]. However, they also act as an opportunistic pathogen, with a high percentage of morbidity and mortality. ranging from superficial infections of the oral, hair, nails, and vaginal yeast infection" to life-threatening as invasive disease Candidemia "bloodstream infection" [12]. 75\% of young female faced at least one infection during their lifetime by Candida spp. [13-14]. Approximately 40-50\% of a young female who had the first infection probably has another one which called "recurrent Candida", and therefore, about 5-8\% suffering from recurrent candida and characterized by three or more infection per year [15]. Candida albicans one of the most pathogens that caused the infection in about $90 \%$ of a young female; additionally, 92-95\% of Candida infection is caused by most popular species: Candida albicans, Candida glabrata, Candida parapsilosis, Candida tropicalis, and Candida krusei [16]. During the past three decades, there was a worrisome increase in resistance in Candida spp. such as Candida albicans, Candida Tropicalis, Candida Parapsilosis, Candida glabrata, Candida Krusei, and Candida lusitaniae [17]. The resistance to Azole groups such as Fluconazole, Voriconazole, and Ketoconazole, and also resistance to last class of antifungal agents Echinocandin [18-19]. Some Candida albicans showed resistance to the first line of Amphotericin B and decreased susceptibility to Caspofungin [20]. Most of the antifungal agents are potentially toxic like Amphotericin B affect the kidney, irregular heartbeat, nervous system, nephrotoxicity, visual effects, nausea, rash, and interactions via cytochrome P450 as the some of Azole group may cause an allergic reaction [21]. The aim of this study was to evaluate the antifungal properties of medicinal plants leaves of C.colocynthis against Candida spp. by broth microdilution assay, agar well diffusion method, and determine the antifungal susceptibility of the isolates by antifungal agents disc.

\section{MATERIALS AND METHODS}

\section{Plant sample collection}

The fresh leaves of Citrullus colocynthis (bitter apple) were healthy, uninfected, and collected from a different area in Khulais, is a governorate in Makkah Province in western Saudi Arabia.

\section{Preparation of extract}

The leaves were washed and air-dried at room temperature $25-30^{\circ} \mathrm{C} .50 \mathrm{~g}$ of the dried powdered leaves were soaked in 500 $\mathrm{mL}$ of sterile distilled water (aqueous) and $80 \%$ methanol for 48 hours and kept in rocking shaker at 75 rpm at room temperat ure $25^{\circ} \mathrm{C}$, then the solution was filtered using filter paper (Whatman no.1), and evaporated by rotary evaporator (Büchi Labortechnike AG, Switzerland) at $40-55^{\circ} \mathrm{C}$. The residue was collected to dry and reconstituted into Dimethyl sulfoxide. (DMSO) $100 \%$. A syringe filter $0.20 \mu \mathrm{m}$ and $0.22 \mu \mathrm{m}$ was used to ensure there is no contamination during the process and stored in sterilized dark container $30 \mathrm{ml}$ in $-80^{\circ} \mathrm{C}$.

\section{Candida isolates}

A total of 6 clinical isolates of Candida spp. were obtained from the clinical microbiology laboratory of Maternity and Children Hospital Makkah al-Mukarramah, Kingdom of Saudi Arabia. The strains were isolated from the urine sample and high vagina swabs (HVS) sample. To ensure the purity of Candida spp., all isolates were subcultured on Sabouraud Dextrose Agar (SDA) (HiMedia, India), with antibiotic chloramphenicol (Sigma-Aldrich, USA), and incubated at $35{ }^{\circ} \mathrm{C}$ for 24 to 48 hours. The identification of the Candida spp. was done by culture on CHROMagar ${ }^{\mathrm{TM}}$ Candida (Paris, France), is a differential media, and contained chromogenic enzyme substrates. The differentiation of Candida spp. based on the color of the colony, Candida albicans appear as a green color, Candida glabrata appear as brown, Candida krusei appear as pink or fuzzy, and Candida tropicalis appear as blue to metallic blue color. The other isolates of Candida spp. such as Candida parapsilosis, and Candida lusitaniae were identified by using the VITEK 2 system (bioMérieux, Marcy l'Etoile, France).

\section{Antifungal activity bioassay \\ Agar well diffusion method}

The antifungal activity of all extracts was performed by agar well diffusion method, described by ${ }^{[22-23]}$ with slight modification. Briefly, Candida spp. strains that grown on Sabouraud Dextrose Agar $35^{\circ} \mathrm{C}$ for 24 hours were suspended in $5 \mathrm{ml}$ of normal saline $0.85 \% \mathrm{NaCl}$. The turbidity was adjusted to $0.5 \mathrm{McF}$ arland $1-5 \mathrm{X} 10^{6} \mathrm{CFU} / \mathrm{ml}$ according to the Clinical and Laboratory Standards Institute ${ }^{[24]}$. The molten Müeller Hinton Agar was poured into each of the sterile Petri plates $20 \mathrm{ml}$ and allowed to solidify. Candida spp. strains were evenly spread with using Sterile cotton swab and allowed to stand for 10 minutes. Five open wells were made in each plate with sterile cork bore $(7.0 \mathrm{~mm}$ diameter). Aliquots $100 \mu 1$ of each test extract was added in each well. The doses were made from $500 \mathrm{mg} / \mathrm{ml}$ to $50 \mathrm{mg} / \mathrm{ml}$. Dimethyl sulfoxide $5 \%$ (DMSO) was used as negative control and incubated at $35^{\circ} \mathrm{C}$ for 24 hours, then the plates were observed for the presence of inhibition of fungi growth that was indicated by a clear zoon around the holes. The zone of inhibition was measured in millimeter.

\section{Minimum Inhibitory Concentration (MIC)}

Candida spp. strains were taken from 24 hours incubation at $35^{\circ} \mathrm{C}$. The turbidity was adjusted to $0.5 \mathrm{McFarland} 1-5 \times 10^{6}$ $\mathrm{CFU} / \mathrm{mL}$ according to the Clinical and Laboratory Standards Institute. The suspension was further diluted (1:50 v/v and 1:20 v/v) in RPMI 1640 medium to obtain a final inoculum of approximately $1-5 \times 10^{3} \mathrm{CFU} / \mathrm{ml}$. 100 $\mu$ l of RPMI 1640 medium was dispensed in each well of 96 well micro-plates. Aliquots of $100 \mu 1$ from starting concentration $100 \mathrm{mg} / \mathrm{ml}$ (aqueous and methanol extract) to made two-fold serial microdilution from $50 \mathrm{mg} / \mathrm{ml}$ to $0.1 \mathrm{mg} / \mathrm{ml}$, then $100 \mathrm{ul}$ was discarded from the last row. Finally, $100 \mu \mathrm{l}$ of 
Candida spp. suspension 1-5x10 $\mathrm{CFU} / \mathrm{ml}$ was added. Row 1 was used as negative control $200 \mu \mathrm{l}$ of RPMI 1640 medium. Row 2 was used as a positive control that contains only $100 \mu 1$ of RPMI 1640 medium with $100 \mu 1$ of Candida spp.1-5x10 ${ }^{3}$ CFU/ml. The microplates were sealed in plastic bags and were incubated for 24 to 48 hours incubation at $35^{\circ} \mathrm{C}$. MIC was determined as the lowest concentration inhibiting the Candida spp. growth, the Phenol Red Indicator was also employed as a growth indicator at the end of the incubation period.

\section{Antifungal susceptibility test}

The Candida spp. isolates were tested by the disc diffusion method. Five different types of antifungal discs Amphotericin

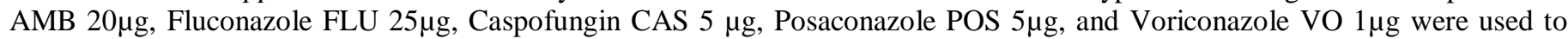
evaluate the susceptibility of Candida spp. The 24 hours colonies were suspended in $5 \mathrm{ml}$ in sterile normal saline $0.85 \% \mathrm{NaCl}$, and the turbidity was adjusted to $1-5 \times 10^{5}-1-5 \times 10^{6} \mathrm{CFU} / \mathrm{ml} 0.5 \mathrm{McFarland}$. The suspension of Candida spp. was swabbed on the solid media Müeller Hinton agar that contains $2 \%$ glucose and $0.5 \mu \mathrm{g}$ of methylene blue/ml and allowed to dry for 10 minutes. Placed five discs, equally spaced, and incubate the plates for $24-48$ hours at $35^{\circ} \mathrm{C}$. The sensitivity was recorded by measuring the clear zone around the discs in millimeter. Breakpoints for the Candida spp. are placed into five categories. These categories include susceptible, intermediate, dose-dependent sensitivity, and resistant. This method was followed as the CLSI has recommended and the manufacturer's instructions ${ }^{[25]}$.

\section{RESULTS}

The agar well diffusion method showed that aqueous and methanol leaves extract were varying at degrees of antifungal activities against tested Candida spp. [Fig. 1]. The antifungal activity of leaves extract was dependent on the dose of the test extract when the concentration of extract increased the diameter of the inhibition zone was also increased as shown in [Table 1-2]. C.krusei and C.lusitaniae showed zone inhibition from $8 \mathrm{~mm}$ to $17 \mathrm{~mm}$ also was noticed the antifungal activity increased with the dose from $100 \mathrm{mg} / \mathrm{ml}$ to $500 \mathrm{mg} / \mathrm{ml}$. Methanol extract showed no activity at all $250 \mathrm{mg} / \mathrm{ml}$ to $50 \mathrm{mg} / \mathrm{ml} \mathrm{except} \mathrm{C.lusitaniae}$. C.albicans was showed strong activity by aqueous extract with zone inhibition from $20 \mathrm{~mm}$ to $14 \mathrm{~mm}$, also the zone inhibition by methanol extract was at range $10 \mathrm{~mm}$ to $17 \mathrm{~mm}$. C.parapsilosis showed that methanol extracts were resistance and no activity observed at $400 \mathrm{mg} / \mathrm{ml}$ to $50 \mathrm{mg} / \mathrm{ml}$ in contrast, aqueous extract was showed strongest inhibition $20 \mathrm{~mm}$ to $10 \mathrm{~mm}$ depending on the doses. C.tropicalis by both leaf methanol and aqueous extract was at zone inhibition between $8 \mathrm{~mm}$ to $14 \mathrm{~mm}$. C.glabrata was the most susceptible to the aqueous extract among all Candida spp. with an inhibition zone ranged from $21 \mathrm{~mm}$ to $13 \mathrm{~mm}$, in case of methanol extract only four doses were affecting the growth from $500 \mathrm{mg} / \mathrm{ml}$ to $350 \mathrm{mg} / \mathrm{ml} 11,10 \mathrm{~mm}$ respectively. The MIC values in [Table 3,4] showed that the lowest concentration inhibited the growth of C.glabrata was at $0.1 \mathrm{mg} / \mathrm{ml}$ and other Candida spp. was at $0.7 \mathrm{mg} / \mathrm{ml}$ except C.albicans $1.5 \mathrm{mg} / \mathrm{ml}$ by the aqueous extract. Whereas, methanol extract was at $6.25 \mathrm{mg} / \mathrm{ml}$ only on C.parapsilosis and C.lusitaniae. The antifungal susceptibility in [Table 5] showed that all Candida spp. were resistance completely to five different types of antifungal discs.

Table 1 The inhibition zone diameters $(\mathrm{mm})$ of leaf aqueous extracts against Candida spp. (500mg-50mg)

\begin{tabular}{|c|c|c|c|c|c|c|c|c|c|c|}
\hline Candida spp. & $\mathbf{5 0 0}$ & $\mathbf{4 5 0}$ & $\mathbf{4 0 0}$ & $\mathbf{3 5 0}$ & $\mathbf{3 0 0}$ & $\mathbf{2 5 0}$ & $\mathbf{2 0 0}$ & $\mathbf{1 5 0}$ & $\mathbf{1 0 0}$ & $\mathbf{5 0}$ \\
\hline C.krusei & 17 & 16 & 15 & 14 & 13 & 12 & 11 & 10 & 8 & $\mathrm{R}$ \\
\hline C.albicans & 20 & 17 & 16 & 16 & 15 & 14 & 13 & 14 & 10 & $\mathrm{R}$ \\
\hline C.parapsilosis & 20 & 19 & 17 & 16 & 15 & 14 & 13 & 14 & 10 & $\mathrm{R}$ \\
\hline C.tropicalis & 14 & 11 & 11 & 10 & 10 & 9 & 8 & $\mathrm{R}$ & $\mathrm{R}$ & $\mathrm{R}$ \\
\hline C.lusitaniae & 17 & 15 & 14 & 13 & 12 & 14 & 12 & 10 & 8 & $\mathrm{R}$ \\
\hline C.glabrata & 21 & 20 & 19 & 17 & 15 & 15 & 14 & 13 & $\mathrm{R}$ & $\mathrm{R}$ \\
\hline
\end{tabular}

$* \mathrm{R}=$ Resistance

Table 2 The inhibition zone diameters $(\mathrm{mm})$ of leaf methanol extracts against Candida spp. (500mg-50mg)

\begin{tabular}{|c|c|c|c|c|c|c|c|c|c|c|}
\hline Candida spp. & 500 & 450 & 400 & 350 & 300 & 250 & 200 & 150 & 100 & 50 \\
\hline C.krusei & 14 & 13 & 13 & 11 & 10 & $\mathrm{R}$ & $\mathrm{R}$ & $\mathrm{R}$ & $\mathrm{R}$ & $\mathrm{R}$ \\
\hline C.albicans & 13 & 9 & 10 & 9 & 9 & $\mathrm{R}$ & $\mathrm{R}$ & $\mathrm{R}$ & $\mathrm{R}$ & $\mathrm{R}$ \\
\hline C.parapsilosis & 14 & 11 & $\mathrm{R}$ & $\mathrm{R}$ & $\mathrm{R}$ & $\mathrm{R}$ & $\mathrm{R}$ & $\mathrm{R}$ & $\mathrm{R}$ & $\mathrm{R}$ \\
\hline C.tropicalis & 13 & 10 & 10 & 9 & $\mathrm{R}$ & $\mathrm{R}$ & $\mathrm{R}$ & $\mathrm{R}$ & $\mathrm{R}$ & $\mathrm{R}$ \\
\hline C.lusitaniae & 12 & 11 & 10 & 12 & 8 & 8 & 7 & $\mathrm{R}$ & $\mathrm{R}$ & $\mathrm{R}$ \\
\hline C.glabrata & 11 & 11 & 11 & 10 & $\mathrm{R}$ & $\mathrm{R}$ & $\mathrm{R}$ & $\mathrm{R}$ & $\mathrm{R}$ & $\mathrm{R}$ \\
\hline
\end{tabular}

$* \mathrm{R}=$ Resistance

Table 3 Minimum Inhibitory Concentration (MIC) values of leaves aqueous extract against Candida spp. (100mg - $0.1 \mathrm{mg}$ )

\begin{tabular}{|c|c|c|c|c|c|c|c|c|c|c|}
\hline Candida spp. & 100 & 50 & 25 & 12.5 & 6.25 & 3.12 & 1.5 & 0.7 & 0.3 & 0.1 \\
\hline C.krusei & - & - & - & - & - & - & - & - & + & + \\
\hline C.albicans & + & + & - & + & - & - & - & + & + & + \\
\hline C.parapsilosis & - & - & - & - & - & - & - & - & + & + \\
\hline C.tropicalis & - & - & - & - & - & - & - & - & + & + \\
\hline C.lusitaniae & - & - & - & - & - & - & - & - & + & + \\
\hline
\end{tabular}


4

Citation: Wael Alsubhi et al., 2019. Antifungal Properties of Citrullus colocynthis Leaves Extracts Against Vaginal Candida Infection. Advances in Environmental Biology 13(2): 1-7. DOI:10.22587/aeb.2019.13.2.1

\section{C.glabrata}

$*_{-}=$NO growth $*+=$ growth

Table 4 Minimum Inhibitory Concentration (MIC) values of methanol extract against Candida spp. (100mg - $0.1 \mathrm{mg}$ )

\begin{tabular}{|c|c|c|c|c|c|c|c|c|c|c|}
\hline Candida spp. & $\mathbf{1 0 0}$ & $\mathbf{5 0}$ & $\mathbf{2 5}$ & $\mathbf{1 2 . 5}$ & $\mathbf{6 . 2 5}$ & $\mathbf{3 . 1 2}$ & $\mathbf{1 . 5}$ & $\mathbf{0 . 7}$ & $\mathbf{0 . 3}$ & $\mathbf{0 . 1}$ \\
\hline C.krusei & - & - & - & - & + & + & + & + & + & + \\
\hline C.albicans & + & + & + & + & + & + & + & + & + & + \\
\hline C.parapsilosis & - & - & - & - & - & + & + & + & + & + \\
\hline C.tropicalis & + & + & + & + & + & + & + & + & + & + \\
\hline C.lusitaniae & + & + & + & + & - & + & + & + & + & + \\
\hline C.glabrata & + & + & + & + & + & + & + & + & + & + \\
\hline
\end{tabular}

$*_{-}=$NO growth $*+=$ growth

Table 5 antifungal susceptibility of Candida spp. Isolates

\begin{tabular}{|c|c|c|c|c|c|}
\hline Candida spp. & AMB & FLU & VO & CAS & POS \\
\hline C.krusei & $\mathrm{R}$ & $\mathrm{R}$ & $\mathrm{R}$ & $\mathrm{R}$ & $\mathrm{R}$ \\
\hline C.albicans & $\mathrm{R}$ & $\mathrm{R}$ & $\mathrm{R}$ & $\mathrm{R}$ & $\mathrm{R}$ \\
\hline C.parapsilosis & $\mathrm{R}$ & $\mathrm{R}$ & $\mathrm{R}$ & $\mathrm{R}$ & $\mathrm{R}$ \\
\hline C.tropicalis & $\mathrm{R}$ & $\mathrm{R}$ & $\mathrm{R}$ & $\mathrm{R}$ & $\mathrm{R}$ \\
\hline C.lusitaniae & $\mathrm{R}$ & $\mathrm{R}$ & $\mathrm{R}$ & $\mathrm{R}$ & $\mathrm{R}$ \\
\hline C.glabrata & $\mathrm{R}$ & $\mathrm{R}$ & $\mathrm{R}$ & $\mathrm{R}$ & $\mathrm{R}$ \\
\hline
\end{tabular}

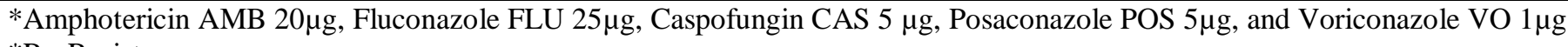
$* \mathrm{R}=$ Resistance

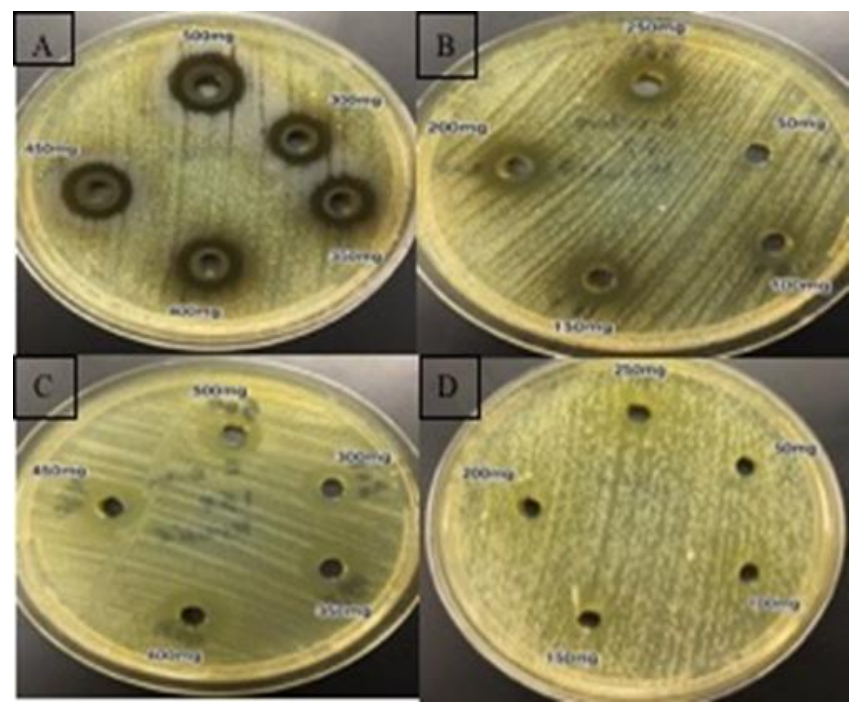

C.krusei A.B leaf aqueous extracts C.D leaf methanol extracts

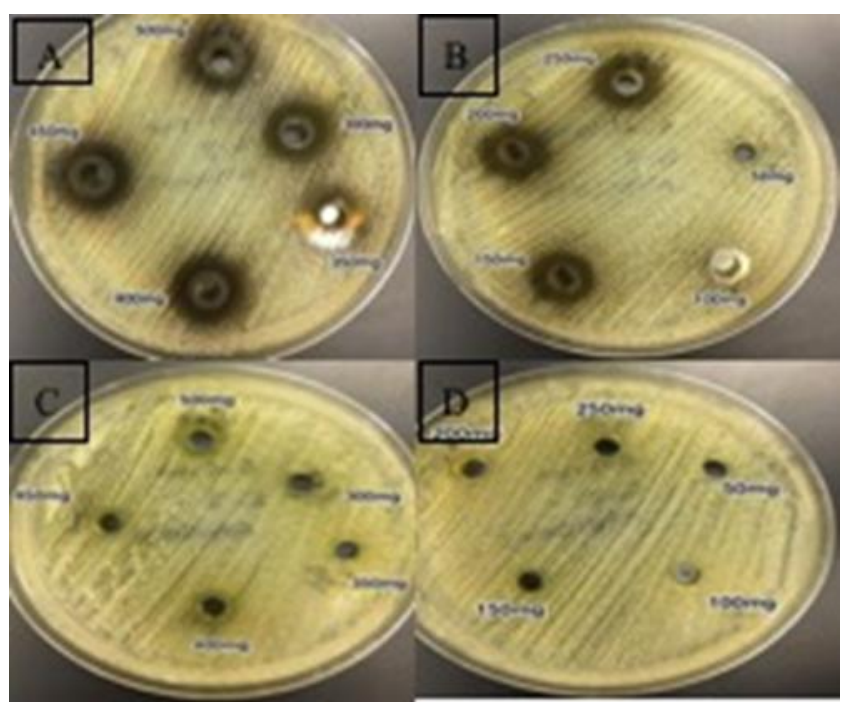

C.albicans A.B leaf aqueous extracts C.D leaf methanol extracts 


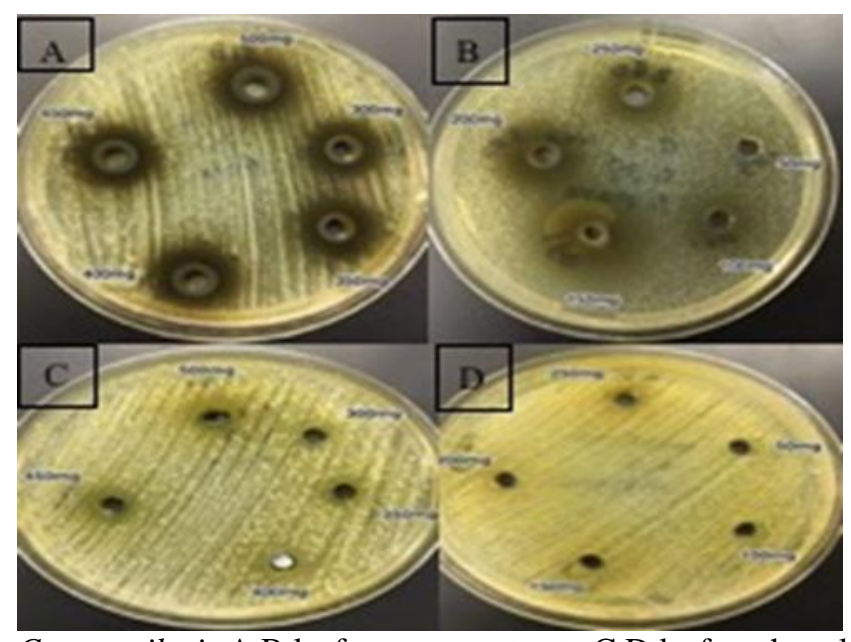

C.parapsilosis A.B leaf aqueous extracts C.D leaf methanol extracts

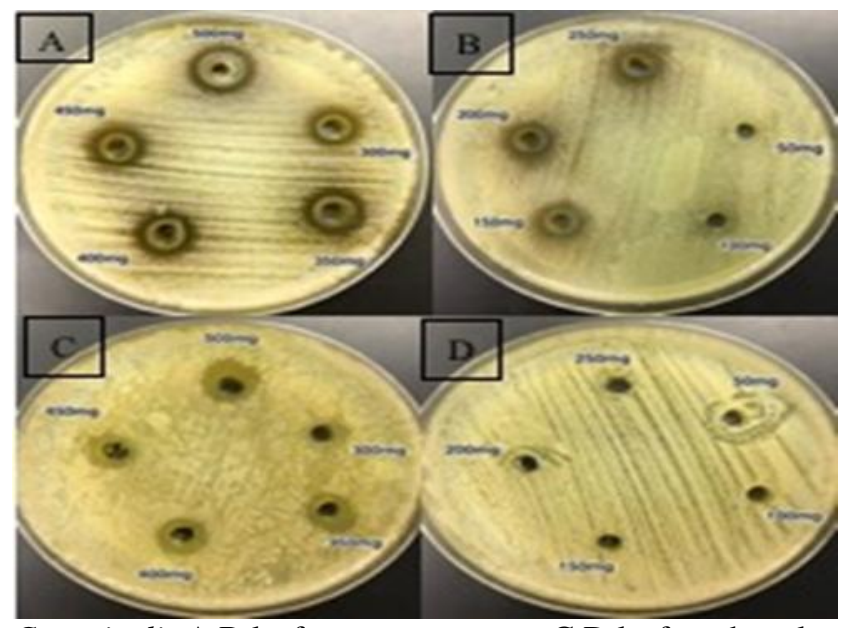

C.tropicalis A.B leaf aqueous extracts C.D leaf methanol extracts

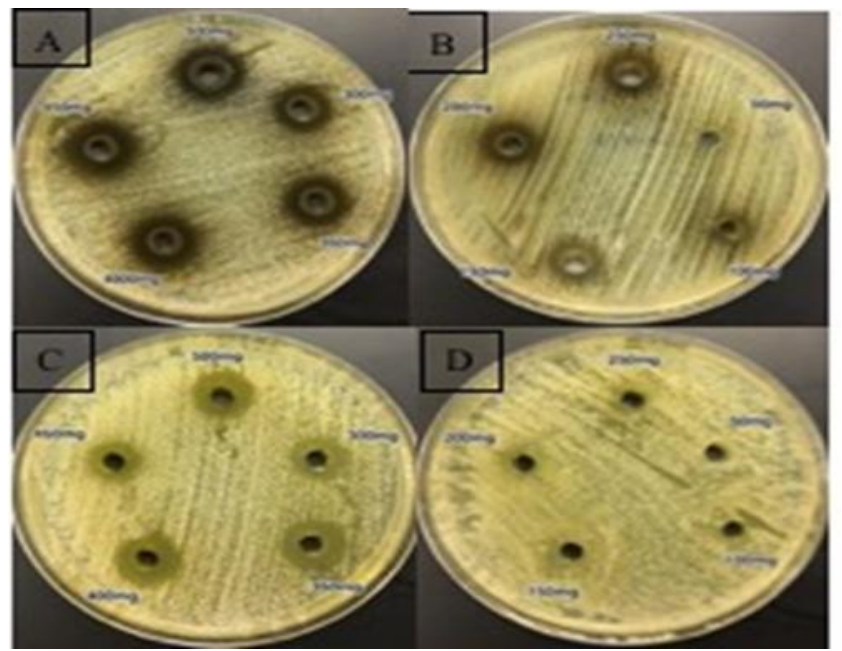

C.lusitaniae A.B leaf aqueous extracts C.D leaf methanol extracts 


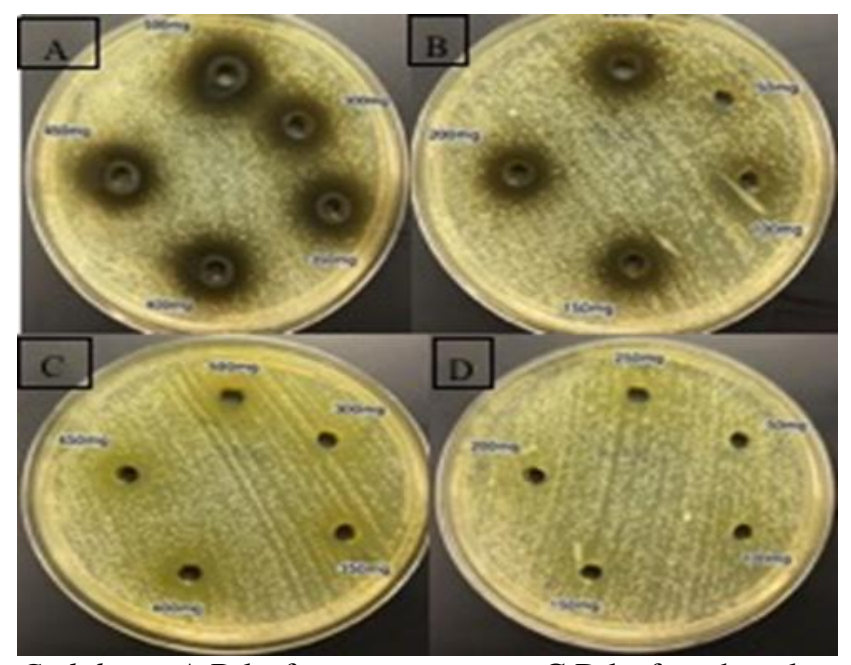

C.glabrata A.B leaf aqueous extracts C.D leaf methanol extracts

Fig 1: agar well diffusion showed that aqueous and methanol leaves extract against Candida spp.

\section{DISCUSSION}

The bioactive compounds of Several plant species have shown promising antifungal, antibacterial activity, and that lead to investigate those bioactive compounds extensively in order to combat the emergence of resistance microorganism [26]. In our study, we found that the leaves of Citrullus colocynthis extracted by aqueous and $80 \%$ methanol showed varying degrees of antifungal activities against tested Candida spp. The leaves aqueous extract showed significant inhibition by agar well diffusion. C.albicans, C.glabrata, and C.parapsilosis were more than $20 \mathrm{~mm}$ at $500 \mathrm{mg} / \mathrm{ml}$ whereas, C.krusei, C.tropicalis, and C.lusitaniae were $17 \mathrm{~mm}, 14 \mathrm{~mm}, 17 \mathrm{~mm}$ at $500 \mathrm{mg} / \mathrm{ml}$ respectively. The leaves methanol extract was between $14 \mathrm{~mm}$ to $11 \mathrm{~mm}$ at $500 \mathrm{mg} / \mathrm{ml}$ for all Candida spp. isolated. Our result showed a high inhibitory activity by leaves aqueous extract and these findings were strong more than what has been reported by [27] with leaf acetone extract on Candida albicans 12mm, and [28] with 95\% ethanol leaf extract was $15 \mathrm{~mm}$. On the other hand, the MIC value exhibited an excellent inhibition more than what reported by [29] who found the lowest concentration ranged from 1.63 to $0.80 \mathrm{mg} / \mathrm{ml}$ without C.tropicalis and C.lusitaniae. The aqueous extract was a good solvent of extraction the bioactive compounds. The inhibitory action of the extracted may attribute to the presence of bioactive compounds which are water soluble like glycosides, tannins, saponins, terpenoids, polypeptides, alkaloids, and flavonoids. Moreover, Different researchers have been suggested many mechanisms of the bioactive compounds as antimicrobial agents, for instance, flavonoids and other groups include flavones, dihydroxyflavone, flavans, flavonols, and anthocyanidins found in $70 \%$ of plants and act like bactericidal, bacteriostatic and antifungal, destructing the cytoplasmic membrane, preventing the process of energy metabolism (ATB), blocking the synthesis of nucleic acids [30]. Therefore, it has been reported that soil conditions, geographical distributions, climatic factor could affect the plants, the season which the plant was collected, the concentration/type of solvents polar or non-polar or mid-polar, the degree of solubility of bioactive compounds, and the extraction method, all these factors may affect the potency of the bioactive compounds [31-32-33].

\section{CONCLUSION}

To our knowledge from literature, this is the first time to evaluate the antifungal activity of plants extracts against Candida spp. that resistance to five types of antifungal agents Amphotericin AMB 20 $\mu$ g, Fluconazole FLU $25 \mu \mathrm{g}$, Caspofungin CAS $5 \mu \mathrm{g}$, Posaconazole POS $5 \mu \mathrm{g}$, and Voriconazole VO $1 \mu \mathrm{g}$. The leaf extract of C.colocynthis has possessed the strongest antifungal activity. This study confirms the fact that medicinal plants possess an important role in diseases prevention, treatment, and have therapeutic uses in traditional medicine also. Further pharmacological and toxicological studies are needful to determine the pure compound and bioactive compounds that have antifungal Properties, which could be novel and develop new antifungal agents for treating the infection.

\section{CONFLICT OF INTEREST}

The authors declare that they have no conflicts of interest.

\section{REFERENCES}

1. Jamshidi-Kia, F., Lorigooini, Z., \& Amini-Khoei, H. 2018. Medicinal plants: past history and future perspective. Journal of herbed pharmacology, 1, 1-7.

2. Nunn and John 2002. Ancient Egyptian Medicine. University of Oklahoma Press. p. 151. ISBN 978-0-8061-35045. 
3. Jamshidi-Kia, F., Lorigooini, Z., \& Amini-Khoei, H. 2018. Medicinal plants: past history and future perspective. Journal of herbed pharmacology, 1, 1-7.

4. http://www.siavitvas.org/images/stories/doc/agopuntura_scientifica/WHOTraditionalmedicine 2008.pdf

5. Ebel, J. 1986. Phytoalexin synthesis: the biochemical analysis of the induction process. Annual review of Phytopathology, 24(1), 235-264.

6. Marles, R. J., \& Farnsworth, N. R. 1995. Antidiabetic plants and their active constituents. Phytomedicine, 2(2), $137-189$.

7. Negi, J. S., Singh, P., \& Rawat, B. 2011. Chemical constituents and biological importance of Swertia: a review. Curr Res Chem, 3(1), 1-15.

8. Kris-Etherton, P. M., Hecker, K. D., Bonanome, A., Coval, S. M., Binkoski, A. E., Hilpert, K. F., ... \& Etherton, T. D. 2002. Bioactive compounds in foods: their role in the prevention of cardiovascular disease and cancer. The American journal of medicine, 113(9), 71-88.

9. Surh YJ. Cancer chemoprevention with dietary phytochemicals. Natural Reviews in Cancer 2003; 3: 768-780.

10. Gove et al 2006, Quan VM, Celentano DD, Moulton LH, Zenilman JM. Prevalence and risk factors for reproductive tract infections among women in rural vietnam. Southeast Asian J Trop Med Public Health. 2006; 37:1859.

11. T.M. Brandolt, G.B. Klafke, C.V. Gonçalves, L.R. Bitencourt, A.M. Martinez, J.F. Mendes, M.O. Xavier, 2017. Braz. J. Microbiol. 48:145-150.

12. Calderone, R. A., Clancy, C. J. (Eds.). 2011. Candida and candidiasis. American Society for Microbiology Press.

13. Yenidunya, S., Hatlas, H., \& Bayrak, R. 2012. To determine the prevalence of Bacterial Vaginosis, Candida sp, mixed infections (Bacterial Vaginosis+ Candida sp), Trichomonas Vaginalis, Actinomyces sp in Turkish women from Ankara, Turkey. Ginekologia polska, 83(10).

14. Adeyeba, O. A., Adeoye, M. O., \& Adesiji, Y. O. 2003. Bacteriological and Parasitological Assessment of Vaginitis in Pregnant Women in Iseyin, Oyo State, Nigeria. African Journal of Clinical and Experimental Microbiology, 4(2), 116-126.

15. Clancy, C. J., \& Nguyen, M. H. 2012. Systemic candidiasis: Candidemia and deep-organ infections. In Candida and Candidiasis, Second Edition (pp. 429-441). American Society of Microbiology.

16. Berkow, E. L., \& Lockhart, S. R. 2017. Fluconazole resistance in Candida species: a current perspective. Infection and drug resistance, 10, 237.

17. Sanguinetti, M., Posteraro, B., \& Lass-Flörl, C. 2015. Antifungal drug resistance among Candida species: mechanisms and clinical impact. Mycoses, 58, 2-13.

18. Pfaller MA, Messer SA, Moet GJ, Jones RN, Castanheira M, 2011. Candida bloodstream infections: comparison of species distribution and resistance to echinocandin and azole antifungal agents in intensive care unit (ICU) and non-ICU settings in the SENTRY Antimicrobial Surveillance Program (2008-2009). Int J Antimicrob Agents, 38:65-69.

19. Castanheira $\mathrm{M}$ et al, 2010. Low prevalence of fks1 hot spot 1 mutations in a worldwide collection of Candida strains. Antimicrob Agents Chemother.54(6):2655-9.

20. Yang $\mathrm{F}$ et al, 2013. Chromosome 5 monosomy of Candida albicans controls susceptibility to various toxic agents, including major antifungals. Antimicrobial Agents Chemother, 57(10):5026-36.

21. D.S. McManus, Chapter 25 -antifungal drugs, in: D.R. Sidhartha (Ed.), Side Effects of Drugs Annual, Elsevier, 2016, 243253.

22. Nenaah, G. 2013. Antimicrobial activity of Calotropis procera Ait.(Asclepiadaceae) and isolation of four flavonoid glycosides as the active constituents. World Journal of Microbiology and Biotechnology, 29(7), 1255-1262.

23. Kareem, S. O., Akpan, I., \& Ojo, O. P. 2008. Antimicrobial activities of Calotropis procera on selected pathogenic microorganisms. African journal of biomedical research, 11(1).

24. Clinical and Laboratory Standards Institute, 2012a. Reference method for broth dilution antifungal susceptibility testing of yeasts; 4th informational supplement. Clinical and Laboratory Standards Institute, Villanova PA

25. Clinical and Laboratory Standards Institute (CLSI). Method for antifungal disk diffusion susceptibility testing of yeasts: approved standard, M44-A. Wayne (PA): CLSI; 2004.

26. Omojate Godstime, C., Enwa Felix, O., Jewo Augustina, O., \& Eze Christopher, O. 2014. Mechanisms of antimicrobial actions of phytochemicals against enteric pathogens-a review. J Pharm Chem Biol Sci, 2(2):77-85.

27. Mahendiran, M., \& Umavathi, S. 2015. In vitro antimicrobial activity of Citrullus colocynthis (Linn.) against selected microorganisms. International journal of current microbiology and applied science, 4(10), 60-69.

28. Shawkey, A. M., Rabeh, M. A., \& Abdellatif, A. O. 2014. Biofunctional molecules from Citrullus colocynthis: An HPLC/MS analysis in correlation to antimicrobial and anticancer activities. Advances in Life Science and Technology, Vol. 17, 2014

29. Marzouk, B., Marzouk, Z., Décor, R., Edziri, H., Haloui, E., Fenina, N., \& Aouni, M. 2009. Antibacterial and anticandidal screening of Tunisian Citrullus colocynthis Schrad. from Medenine. Journal of ethnopharmacology, 125(2), $344-349$.

30. Ahmad, A., Kaleem, M., Ahmed, Z., \& Shafiq, H. 2015. Therapeutic potential of flavonoids and their mechanism of action against microbial and viral infections-A review. Food Research International, 77, 221-235.

31. Eltayeb, I. M., \& Nari, F. H. M. 2017. Phytochemical screening, antioxidant and antimicrobial activities of some Sudanese medicinal plants against standard and isolated microorganisms. Journal of Pharmacognosy and Phytochemistry, 6(5), 97-100.

32. Alade, P. I. and Irobi, O. N. 1993. Antimicrobial Activities of Crude Leaf Extracts of Acalypha wilkesiana. Journal of Ethnopharmacology 39: 171- 174.

33. Iwu, M. M. 2000. Empirical Investigation of Dietary Plants used in Igbo Ethnomedicine: Vol 2, Cesta Press Enugu; Nigeria. pp. 4-5 